\title{
A Frank Exchange of Views: Communicating through Violence in Ireland, 1565-1610
}

John Patrick Montaño

\section{(2) OpenEdition \\ 1 Journals}

\section{Electronic version}

URL: http://journals.openedition.org/etudesirlandaises/5291

DOI: 10.4000/etudesirlandaises.5291

ISSN: 2259-8863

\section{Publisher}

Presses universitaires de Caen

\section{Printed version}

Date of publication: 29 November 2017

Number of pages: $47-57$

ISBN: 978-2-7535-7388-8

ISSN: 0183-973X

\section{Electronic reference}

John Patrick Montaño, «A Frank Exchange of Views: Communicating through Violence in Ireland, 1565-1610», Études irlandaises [Online], 42-2 | 2017, Online since 29 November 2017, connection on 20 September 2019. URL : http://journals.openedition.org/etudesirlandaises/5291 ; DOI : 10.4000/ etudesirlandaises.5291 


\title{
A Frank Exchange of Views: Communicating through Violence in Ireland, 1565-1610
}

\author{
John Patrick Montaño \\ University of Delaware
}

Abstract

The introduction of agriculture to supplant the pastoral society of Ireland was at the heart of the civilizing mission in Ireland after 1530. But the altered landscape and material culture associated with this change in land use soon served as new points of cultural conflict, with hostility and resistance from both sides directed at objects as well as symbols and members of the two cultures. The emerging violence in Tudor Ireland will be read here as a type of text for communicating difference.

Keywords: Agriculture, Landscape, Material Culture, Cultural Conflict, Violence, Communicating Difference

\section{Résumé}

L'introduction de l'agriculture pour supplanter la société pastorale de l'Irlande fut au coeur de la mission civilisatrice entreprise dans le pays après 1530. Mais la modification des paysages et la culture matérielle associée à cette mutation dans l'usage de la terre servirent bientôt de nouveaux points de désaccords culturels, où l'hostilité et la résistance des deux côtés furent dirigées contre les objets aussi bien que les symboles et membres des deux cultures. La violence émergente dans l'Irlande Tudor sera représentée ici comme un type de texte où s'exprime la communication de la différence.

Mots clés : Agriculture, Paysage, Culture Matérielle, Désaccords Culturels, Violence, Communication de la Différence

S. J. Connolly's work on Contested Ireland has revealed the extent of cooperation and coexistence in early modern Ireland; this alternative to the assumptions about inveterate conflict are surely welcome, but the trope of Irish incivility remained potent throughout the period ${ }^{1}$. The allegedly barbarous nature of Ireland, rooted in cultural differences exemplified in land use, the erection of permanent buildings, fences, roads, clothing, hair and language opened spaces for cultural conflict that regularly took the form of destruction and violence on both sides. Significantly, the destruction and violence was often directed at cultural objects as well as people. One

1. S. J. Connolly, Contested Ireland: Ireland 1460-1630, Oxford, Oxford University Press, 2007. 
way to understand these actions is to examine the cultural and political meanings of violence in Ireland in the light of the cultural differences that informed the civilizing process and plantations. In particular, the way that such violence served as a form of communication or performance in these years.

Scholars have written of executions and pardons as instruments for communicating state power through violence or mercy, but in each case as a demonstration of a restoration of the appropriate political order disrupted by offenders. This posed a particular problem in Ireland, as the legitimacy of the state was not yet recognized in many areas, the Irish as Catholics could never be true subjects, and for many like Spenser, pardons could never work in Ireland due to the barbarous incivility of the natives ${ }^{2}$. Thus, the ongoing disorder in Ireland meant that the violence there, intended on one side to demonstrate the power and authority of the state, might also take the form of resistance and defiance on the other. So while much violence was retributive in nature, it will be the goal here to turn to some examples and to understand how they might be viewed as texts and that they were filled with meaning and clearly intended as communicative. English writers in the 1500s recognized the way that language often served to inhibit or to get in the way of communication. A perfect example of this is the use of agricultural metaphors to portray Ireland as savage and barbaric, a wild and neglected place in need of cultivation. Regarding this Eamonn Grennan writes: "it is an easy transition from here to the metaphorical notion of the Irish as uncultivated ground in which a civil state must be planted." The ideas of planting civility, of cutting off evil customs, of pruning branches and ripping up weeds in order to allow the land to bear fruit are all images drawn from the benign activity of husbandry. But once the ripping up becomes dispossession, the pruning and cutting off become murder and executions, and the planting becomes colonization then the metaphors are difficult to sustain "in the context of political fact ${ }^{3}$ ". More to the point, when language and metaphors are used to communicate a superior culture or to justify a particular form of civility then the response often takes the shape of resistance to the more concrete non-textual expressions of the culture being promoted. With that in mind, I want to try to read cultural confrontations as texts, or a form of communication that demonstrate the awareness - on both sides of the divide - of the essential distinctions situated in cultural differences ${ }^{4}$.

2. Peter Lake and Michael Questier, "Prisons, Priests and People", in England's Long Reformation, ed. Nicholas Tyacke, London, Routledge, 1998, p. 196; K. J. Kesselring, Mercy and Authority in the Tudor State, Cambridge, Cambridge University Press, 2003, p. 144, 185.

3. Eamon Grennan, "Language and Politics: A Note on Some Metaphors in Spenser's A View of the Present State of Ireland", Spenser Studies 3, 1982, p. 101, 106-07. The importance of agricultural metaphors is also discussed in Nicholas Canny, "Edmund Spenser and the Development of an Anglo-Irish Identity", Yearbook of English Studies 13, 1983, p. 7-14.

4. The preceding paragraph is based on ideas, expressed far more eloquently, by Patrick J. Wolfe in his Plenary 
An early example of violence being conflated with symbolic actions can be seen in the fact that the Proclamation offering a reward for Shane O'Neill's "head, body, or proof of having killed him," was careful to include his symbolically provocative act of entering "the Englisshe Pale... with banners displayed, as an open enemye, traitour, and rebel." Shane was making no secret of his defiance and disrespect, and people in London marveled at his hostility and enmity. Camden was incensed and even a bit befuddled that,

with barbarous Pride hee [Shane] rejected all such honourable Titles, in comparison to the name of O-Neal... and boiled in Hatred against the English, in such sort, that he named a Castle which he built in the Lake Eaugh $[s i c]$, Feoghnegall, that is, The hatred of the English, and strangled some of his own men for that they fed on English bread'.

Shane's rejection of English titles and authority is understandable, and his animosity towards his enemies not at all surprising. The resentful name ascribed to his castle was, if nothing else, the English projecting their habit of encoding cultural differences. More significant here is the tale that he asserted his cultural hostility by executing some followers for eating "English bread", the most emblematic product of cultivated fields. Here we see the bitter cultural dialogue in Ireland finding common ground that would lead to several frank exchanges of views in the years to come.

Shane's decision openly to defy the queen's authority and laws by displaying his banners, was a performative act intended as much for his Irish followers as for officials in Dublin and London. In the event, it helped commit the government to his destruction, and whatever role Sidney or others may have had in his murder, the elimination of O'Neill was far too great a triumph to allow to pass unnoticed. The Scots for their own reasons "hewed him to peeces..." even burying him "wrapped in a kernes shirt, and so without all honor", but such limited ignominy was insufficient for O’Neill's English enemies. "After a few daies he was taken up againe by capteine Piers... and his head was sund[e]red from the bodie, and sent to the lord deputie who caused the same to be set upon a stake or pole on the top of the castle of Dublin ${ }^{6}$." In a perfect example of how the

Lecture, "Beyond the Pale(stine) of Settlement: Settler Colonialism, Its Barriers and Its Contradictions," 27 June 2007, Fifth Galway Conference on Colonialism. One is also reminded of Sean Ó Tuama's claim that the "Tudor subjugation of Ireland may well have been unique in the attention paid to cultural as well as territorial conquest".

5. Proclamation of Shane O'Neill as Traitor, HMC, Haliday MSS, (1897), 174, 2 August 1566; William Camden, Annales: the True and Royall History of the Famous Empresse Elizabeth, London, 1625, p. 167. It should be noted that Camden wrote later and the story may be apocryphal.

6. Richard Holinshed, Chronicles of England, Ireland and Scotland, 2 vols., London, John Harrison, 1587, p. 117. Sidney relates his reception of the gory trophy, "pickled in a pipkin", in his Memoir, Ciarán Brady (ed.), A Viceroy's Vindication? Sir Henry Sidney's Memoir of Service in Ireland, Irish Narratives, Cork, Cork University Press, 2002, p. 53. 
emphasis on civility, cultivation, land, and rituals were conflated into a single strategy, when Sidney captured Shane's treasure on Coney Island, he took anything not nailed down, but also renamed it Island Sidney and the largest lake in Ulster Lough Sidney. The deputy's triumphalist humiliation of Shane O'Neill contributed to the growing trend of public, symbolic, ritualized displays of enemies being brought low and degraded by both sides in the conflict. Similarly, the cultural and cartographic erasure of the O'Neill stronghold [and Lough Neagh] was another sign of both the reformed landscape and of the English determination to remain. Indeed, such official alterations and public performances formed a key element in the cultural conflict in Elizabethan Ireland ${ }^{7}$.

For both sides, performative rituals and symbolic actions played an important role in communicating power and defiance. Writing about the texts available for an analysis of political ideology in Ireland, Hiram Morgan reminds us that "the transmission of ideas was not only multilingual, it was also multimedia," and laments that there is "no analysis of the rituals whereby the state attempted to project its power or of the Gaelic and Catholic alternatives used to undermine it." Similarly, Chandra Mukerji points to the relevance of material culture and other forms of evidence when studying the illiterate or oral cultures, emphasizing the visual rather than written records, and the importance of vision, actions, and ritual over words $s^{8}$. Spiking Shane's head on Dublin Castle was more than a representation of state power, it was an undeniable and grisly demonstration of it. For the Irish, it did not take much imagination to develop their own set of symbolic actions designed to indicate their defiance and disdain for official authority. As Clodagh Tait shows, the propaganda value of the appropriate death of a member of one's own group, or the inappropriateness of the death of one's enemies was hugely important for establishing the justice or iniquity of the cause. On the one hand, the spectacle of power and the admonitory display of state power could not impress the Irish as it was rooted in injustice, while on the other hand the attacks on settlers, their lands and possessions was viewed as further evidence of their savagery, inhumanity, and irredeemability?.

Canny argues that an incipient Irish political consciousness accounts for "morbid concern with the ritual humiliation performed by the Irish on the

7. Hiram Morgan, "Overmighty Officers: the Irish Lord Deputyship in the Early Modern British State", History Ireland, Winter, 1999, p. 18. According to Morgan, Sidney later returned to Whitehall leading 200 Irish gentlemen "in echoes of a Caesarean triumph".

8. Hiram Morgan (ed.), Political Ideology in Ireland, 1541-1641, Dublin, Four Courts Press, 1999, p. 20, 57; Chandra Mukerji, Territorial Ambitions and the Gardens of Versailles, Cambridge, Cambridge University Press, 1997, p. 315.

9. Patricia Palmer, "An Headlesse Ladie' and 'a Horse Loade of Heades': Writing the Beheading", Renaissance Quarterly 60 (2007): 31; Clodagh Tait, Death, Burial and Commemoration in Ireland, 1550-1650, New York, Palgrave, 2002, p. 6, 20. 
corpses of soldiers killed in battle - rituals that were quite obviously in direct imitation of English practice ${ }^{10}$ ". While the continuing failure of the English to subdue the natives no doubt contributed to their use of brutality as a means to reduce costs, it is undeniable that violence speaks volumes and that people on both sides were determined to communicate with their violence. At the same time, public spectacles intended to publicize the defeat and submission of Irish leaders and the elimination of native culture remained part of the official campaign to make known the inexorable advance of civility ${ }^{11}$. However, it is indicative of the centrality of the ideology and rhetoric of civility that the Irish accepted the importance of such actions, and increasingly relied on them to contest the cultural strategy that underpinned official policy in Ireland.

One example is the way Sidney sought to communicate the ongoing metamorphosis in Ireland through ceremonies, submissions, executions, and the creation of material culture representing the new civil society emerging in the island. One of his most prominent achievements in this realm was the stone bridge built across the Shannon at Athlone. From a strategic point of view, Sidney boasted that the bridge was a means to tame "all Connacht [so] that now [the Irish] dare not stir to any rebellion". But from a cultural and communicative standpoint, the bridge was intended as an expression of aesthetic and political messages, and an "assertion of cultural and military might ${ }^{12}$." The solidity of the bridge indicated clearly the settlers' intention to stay, to replace, to remove and to install their own institutions and culture. Sidney's plaque also announced the recent political changes, stating "THE ARCHE REBEL SHANE O NEYL OVER THROWEN [AND] HIS HEAD SET ON THE GATE OF THE SAID CASTEL ${ }^{13}$ ".

In the same way that Sidney hired masons to magnify his own accomplishments in Ireland, he also took care to make sure the spoken and printed word were monitored carefully to limit their exploitation by those hostile to English

10. Nicholas Canny, "Dominant Minorities: English Settlers in Ireland and Virginia, 1550-1650", Historical Studies 12, 1977, p. 59, 62-63; Christopher Maginn, "Civilizing" Gaelic Leinster: The Extension of Tudor Rule in the O'Byrne and O'Toole Lordships, Dublin Four Courts Press, 2005, p. 104.

11. Padraig Lenihan and Clodagh Tait David Edwards, ed., Age of Atrocity: Violence and Political Conflict in Early Modern Ireland, Dublin, Four Courts Press, 2007, p. 22. David Edwards points out that, "the deliberate butchery of large numbers of defenseless people was no longer deemed dishonorable", even though it was unprecedented, in the years after Henry's death. He lists among other examples 200 O'More kerne in 1547 , 140 O'Neills in 1549, 200 MacDonnells in 1556, 74 O'Tooles in 1556, and the butchery of the MacDonnells while asleep and at peace in 1563 , ibid., p. 72.

12. Sidney to Cecil, 1566, quoted in John Bradley, "Sir Henry Sidney's Bridge at Athlone, 1566-7", in Ireland in the Renaissance c. 1540-1660, ed. Thomas Herron and Michael Potterton, Dublin, Four Courts Press, 2007, p. 173; Harman Murtagh, Athlone: History and Settlement to 1800, Athlone, Old Athlone Society, 2000, 42. Bradley notes that some of the stone used in the bridge came from the Franciscan friary nearby, another example of the logic of elimination whereby objects like the friary were culturally destroyed by being transformed into a symbol of settler control.

13. Bradley, "Sidney's Bridge at Athlone", p. 184. 
influence and order. During a visit to Kilkenny Sidney was appalled by the Butlers' willingness to patronize Irish poets who sang the praises of Butler's military prowess, and ordered "all the Irish poets in the vicinity of Kilkenny... arrested, divested of their belongings, whipped, and ordered to leave the region ${ }^{14 "}$. But just as the poets and their neighbors found themselves on the receiving end of the same harsh messages, they soon learned to use the language of cultural communication. When Sir Francis Cosby boasted of taking 125 O'More and O'Connor heads in 1564, Rory Óg O'More's response included the massacring of settler husbandmen and the decapitation of any English soldiers he laid his hands on $^{15}$. For both sides, the barbarity of their enemies demanded a balanced and parallel level of savagery. And throughout the 1560s and 70s the use of violence became the primary text and language of communication in Ireland.

One of the first examples of triumphalist symbolism occurred at the end of 1568, when Carew sallied out of Kilkenny and "caused great execution to be done upon a great number of Edward Butler's followers". The slaughter of over four hundred galloglass may have been welcome, but the carnage that ensued as 1600 others attempted to flee with "few or none escap[ing]", shocked even the citizens of Kilkenny, no doubt aware that Carew's claim to have lost not single man in an attack on 2000 meant that most of the victims were unarmed and unprepared for battle. As a way of celebrating his victory (and concealing the number of innocents), Carew returned to Kilkenny with "everie capteine and souldier carrying two Gallowglasses axes in his hand ${ }^{16 "}$. Well accustomed to these public displays of Irish defeats and the manipulation of imagery intended to deride native customs through an "expressive lexicon" of actions that contained "a communicative logic that all could understand", the rebels learned to engage in symbolic violence in turn ${ }^{17}$.

During the Butler Revolt of 1569, Sidney learned that the Butlers "are become friends to the Geraldines and hath sworne to take the hedde of all such as shall confesse themselves to be true subjects unto the Queene ${ }^{18 "}$. Similarly, the ear-

14. David Edwards, The Ormond Lordship in County Kilkenny, 1515-1642: The Rise and Fall of Butler Feudal Power, Dublin, Four Courts Press, 2003, 189; David Edwards, “The Butler Revolt of 1569”, IHS 38, no. 111, 1993, p. 243; David B. Quinn, "Government Printing and the Publication of the Irish Statutes in the Sixteenth Century”, Proceedings of the Royal Irish Academy 49, Section C, 1943, p. 46, 55, 66.

15. Vincent P. Carey, “The End of the Gaelic Political Order: the O'More Lordship of Laois 1536-1603”, in Laois: History and Society, ed. Padraig G. Lane \& William Nolan, Dublin, Geography Publications, 1999, p. 227230.

16. PRO SP 63/26/59, Carew to Sidney, 26/12/68; John Hooker, Holinshed's Chronicles of England, Scotland and Ireland, 2 vols, London, John Harrison, 1587, 2:130; Thomas Leland, The History of Ireland from the Invasion of Henry II, 3 vols., London, Nourse, Longman, Robinson \& Johnson, 1773, 2, p. 250.

17. David Cressy, "Different Kinds of Speaking: Symbolic Violence and Secular Iconoclasm in Early Modern England", in Protestant Identities: Religion, Society, and Self-fashioning in Post-Reformation England, ed. Muriel C. McLendon and Joseph P. Ward and Michael McDonald, Stanford, Stanford University Press, 1999, p. 19-22. 18. PRO SP 63/28/38, Jaspar Horsey to Sidney, 18 June 1569; Brady (ed.), A Viceroy's Vindication, p. 64. 
liest settlers in the Midlands were singled out by the rebels, with many led about in halters and their cultivated fields, fences, and homes destroyed. The Butlers overran Queen's County and killed "very many of the inhabitants of the same, but most specifically all the Englishmen", and all the farmers in the area put to the sword. Sir Edmund Butler's rage reached such a pitch that he exhibited his hatred of English settlers by having "dead men's bodies to be stripped out of their English garments and their hose and doublets (being stuffed with straw) he would set up as marks for his kernes to throw their darts at ${ }^{19}$. Again we see the English and the several manifestations of their civility and culture made the target for native anger and defiance. The official determination to eliminate the barbarous customs of the natives was clearly understood by those in Ireland; but the scattered revolts in 1569 make it plain that the objects of the English colonial strategies were perfectly capable of speaking the language of cultural contestation.

Consequently, the regular markets and fairs intended to regulate trade became targets for native hostility. 1569 saw the Assumption Day fair at Enniscorthy turned into an all too convenient opportunity for pillage. The hostility to the agents of the commercial aspects of English culture at a "fair [that] is far the greatest of any in Ireland," was noted by Sidney, who condemned the Irish for attacking "most of the merchants of the good town of Washford, either in their own persons, their wives or their servants, who were ravished, killed or spoiled ${ }^{20}$ ". Here we see rebels in Ireland able to recognize the symbols of a foreign culture and economy and attacking towns, fairs, merchants, "and their Irish adherents" because of their association with the English. Forces on both sides were accustomed to communicating with their violence, using it as a form of performance that carried both symbolic and practical messages. Butler put much of the town to the sword, drove others into the river Slaney to drown, and unleashed an orgy of rape before setting Enniscorthy on fire: the prospect of booty was attractive, but demonstrating the power of the rebels and the state's inability to protect its subjects provided a message of strength and defiance ${ }^{21}$.

The response to these actions was led by one of the great communicators through violence, Sir Humphrey Gilbert. He took it as practice "infringeable"

19. James Hughes, "Sir Edmund Butler of the Dullogh", Journal of the Royal Historical and Archaeological Association of Ireland 4th series, 1, 1870, p. 185; Steven G. Ellis, Ireland in the Age of the Tudors 1447-1603: English Expansion and the End of Gaelic Rule, New York, Longman, 1998, p. 293; Brady (ed.), A Viceroy's Vindication, p. 62; Hubert Butler, "An Anti-English Butler", Journal of the Butler Society 1, 1968, p. 23; Richard Bagwell, Ireland under the Tudors, 3 vols., London, The Holland Press, 1885-90, 2: p. 156. Sir Edmund, captain and seneschal of the Butler forces, characterized Sidney's attacks on coyne and livery as the deputy expecting him "to ride up and down the country like a priest", Viceroy's Vindication, p. 62.

20. HMC Salisbury MSS, 1: 417, Richard Walshe to the Lord Chancellor, 17 August 1569; Hughes, "Sir Edmund Butler", 191-197; AFM, s.a. 1569; Brady (ed.), A Viceroy's Vindication, p. 63.

21. David Edwards (ed.), introduction, 22. Butler sent a similar message when he killed the women and children in Shillelagh after their men had fled before him, Bodleian Library, Carte MS 131, fo. 83, 1568. 
that whenever arriving in rebel territory "he killed manne, woman, and child, and spoiled, wasted, and burned, by the ground all that he might: leaving nothyng of the enemes in safety, which he could possiblie waste, or consume, freely admitting that killing any and all civilians "by the sworde was the waie to kill the menne of warre by famine". Years later, Fitzwilliam was instructed that "such notorious indecencies, even to the invasion of and spoiling of the Englishe pale, may not be suffered to pass without some example of justice". Furthermore, these examples were not intended simply to punish the native leaders, but also "for the terror of others that... [otherwise] may be otherwise hereafter eftsones incouraged to do the like". Here we see the emphasis on the role of spectacle and the significance of imagery and display, but as always the violence inflicted on images, symbols, and natives would soon be returned in kind ${ }^{22}$.

Destroying recently built houses was not only a statement of hostility to English civil norms, for the Burkes' had a much more particular point to make. They turned their rage against those contributing to the material culture that most offended them, and "bett away the masons and other laborers wich were workinge in the wall (appointed by me [Sidney] to be made in Aprill last...) and sought for the stones where upon the [royal] Armes were cutt, [in order] to have broken them, swearing that none such should stande in any wall there ${ }^{23}$ ". It is clear that the rebels were joining Sidney and others in their acceptance of architecture as a canvas for the assertion of and cultural political messages. The centrality of cultural conflict in Tudor Ireland can be seen in the Burkes recognition that clothes, houses, walls, and gates were as significant as the display of the royal arms in Connacht and that their resistance needed to incorporate them all.

In the same year, Sir Thomas Smith's venture in the Ards ended with his son being murdered by an Irishman of his own household, then boiled, and fed to the dogs, an incident that gave "the Irishmen greate cause of rejoisinge." Unwilling to tolerate such barbarous behavior, Nicholas Malby hunted down Smith's murderer, "slew him likewise... and so left him to the Wolves jaws, to be devoured and eaten ${ }^{24 "}$ " Camden's "likewise" illustrates how well people at the time, and annalists later, grasped the significance of violence as a means of expression. Far from being mindless or random, Malby's violent response was an appropriate means to dramatize the importance of official power, an act that was extremely visible and

22. Bodleian Library, Carte MS 57, fo. 403, Council in England to Fitzwilliam, 22 August 1572; Cressy, "Different Kinds of Speaking", p. 19, 21.

23. PRO SP 63/56/6; Sidney's letter is printed in, Arthur Collins, Letters and Memorials of State in the Reigns of Queen Mary, Queen Elizabeth, King James, King Charles the First, Part of King Charles the Second and Oliver's Usurpation, 2 vols. (London, 1746), 1: p. 119. The meaning of the Burkes's actions were readily understood at the time and after, with Camden explaining that they, "with a barbarous hatred which they bore unto them who began to favor Lawes and Humanity, killed the workmen", Camden, Annales of Elizabeth, p. 368.

24. PRO SP 63/42/55, Essex to the Privy Council, 20 October 1573; Camden, Annales of Elizabeth, p. 319. 
entirely unambiguous. English lives and bodies were precious and sacrosanct, Irish ones were not ${ }^{25}$.

The justification for the atrocities and massacres received its greatest explication in the works of Edmund Spenser, but the language of chastisement and castigation was a key component in the official discourse under Elizabeth ${ }^{26}$. The increasing savagery - manifested most often in the slaughter of noncombatants was no doubt related to the religious divisions after 1534, but New English officers were regularly praised for their willingness to rely on fire and sword when dealing with the Irish. As Nicholas Canny shows, Spenser and his circle advocated a humanistic use of the sword, "fierce wars", and "virtuous action" as the best strategy for eliminating barbarous Irish customs and creating the tabula rasa most suited to receive whatever imprint the government $\operatorname{chose}^{27}$.

Remarkably, Leicester - like so many reformers before him - had never been to Ireland, yet was fully persuaded by others that the Irish were "a proud, dissembling, and malicious people and always unfaithful." Accordingly, for Leicester there could be only one solution: "Such a people therefore deserves continually ye rodd, and syldome to be stroked on the hedd." Nearly a year later he was sending the Lord Deputy similar advice, reminding him that the Irish were accustomed to "evill lyving as wyld savages... [so nothing] but the sword must keep them under". As a leader of the puritan faction at court, Leicester prayed that he might live to see the "governor of that land not to sprare the sword, nor to ceasse contynuall following the marshall $[$ sic $]$ trade... for law ys lost upon such, till theye first know obedience and fear ${ }^{28}$ ". By 1590 the discourse of virtuous use of the sword, muscular humanism, and the association of violence and reform would be a commonplace in the writings of Edmund Spenser, Lodowick Bryskett, Barnabe Rich, John Derricke, William Herbert,

25. David Riches, "The Phenomenon of Violence", in The Anthropology of Violence, ed. David Riches, Oxford, Basil Blackwell, 1986, p. 11-12.

26. In Patricia Palmer's view, Spenser was by no means the first writer to advocate brutality, just the first one to justify it in the name of humanism. Far from being morally objectionable, the savagery is in fact virtuous, William Palmer, "That 'Insolent Liberty': Honor, Rites of Power, and Persuasion in Sixteenth-Century Ireland", Renaissance Quarterly 46, no. 2, 1993, p. 323.

27. Canny, "Spenser and Anglo-Irish Identity", 6; Nicholas Canny, Making Ireland British, 1580-1650, Oxford, Oxford University Press, 2001, p. 14; Canny, "Dominant Minorities"; Nicholas Canny, "Introduction: Spenser and the Reform of Ireland", in Spenser and Ireland: An Interdisciplinary Perspective, ed. Patricia Coughlan, Cork, Cork University Press, 1989, p. 10-14; David Edwards, "Ideology and Experience: Spenser's View and Martial Law in Ireland", in Political Ideology in Ireland, 1541-1641, ed. Hiram Morgan, Dublin, Four Courts Press, 1999, 149-55; Patricia Coughlan, "'Some Secret Scourge which Shall by Her Come unto England': Ireland and Incivility in Spenser", in Spenser and Ireland: An Interedisciplinary Perspective, ed. Patricia Coughlan, Cork, Cork Universiy Press, 1989, p. 50-61.

28. Bodleian Library, Carte MS 56, fos. 103-5, Leicester to Fitzwilliam, 5 December 1572 and ibid., fos 220220v, 26 October 1573; see PRO SP 63/56/34, Malby to Elizabeth, 20 September 1576 and ibid., 63/68.46i, Fitzwilliam Remembrance, 1579, for more of the same on the need for severity. 
Richard Beacon, Barnaby Googe and the host of Irish officials linked to the Leicester and Sidney faction at court.

Similarly, officials soon justified and praised the eradication of barbarism and the savage people it sustained with agricultural imagery as well. Turning to agriculture and cultivation for metaphors to convey the need for atrocities, Holinshed commended Perrot in 1573 for executing "infinite numbers... and having thus rid the garden from the weeds, and rooted up the fields from these thornes". William Camden condemned the Burkes for destroying Athenry again in 1576, recognizing that they did so owing to the "barbarous hatred which they bore unto them who began to favor Lawes and Humanity", while Holinshed reduced the problem to a simple horticultural matter:

As the husbandman then prospereth best, when his fields and gardens are weeded and clensed from thornes, brambles, and briers, prepared for the fire, even so shall the magistrate injoie the quiet state of the commonwealth when justice taketh place... and the wicked (prepared for the gallows) according to their deserts punished ${ }^{29}$.

The Irish Council wrote to the second earl of Essex about the continuing problems in Ulster by saying that "those monstrous treasons took their first root there, and from thence have poisoned all the other provinces of the realm, and therefore [it is] requisite to have a main blow stricken at this root, the sooner to shake and scourge all the branches that are grown out of it ${ }^{30}$ ". The very imagery that justified planting of Englishmen could also be used to advocate the uprooting and pruning of the Irish.

The claim that O'Neill was "the very root, or seedman of all the rebellion in Ireland", may seem metaphorically benign, but when read alongside Spenser's development of the idea it takes on a more menacing tone. For Spenser the only sure instrument for reforming Ireland was "the sword; for all these evills must first be cut away by a strong hand, before any good can bee planted, like as the corrupt braunches and unwholesome boughs are first to bee pruned, and the foule mosse cleansed and scraped away, before the tree can bring forth any good fruite ${ }^{31}$. In the View, the "evils" to be eliminated are Irish customs, but is clear that the blunt tools used for the pruning would make no distinction between people and plants.

29. Hooker, Holinshed's Chronicle, op. cit., 2: p. 134, 141; Camden, Annales of Elizabeth, p. 368.

30. CSP Ireland, 1574-85, 1? Malby to Elizabeth? October 1576; Walter Bourchier Devereux, Lives and Letters of the Devereux Earls of Essex in the Reigns of Elizabeth, James I, and Charles I, 2 vols. London, John Murray, 1853, 2: p. 24, Irish Council to Essex, November 1575; Philip H. Hore, The History of the Town and County of Wexford, 6 vols., London, Elliot Stock, 1899-1911, 6, p. 99.

31. PRO SP 63/82/45, Bryskett to Walsingham, 21 April 1581; Edmund Spenser, A View of the State of Ireland: From the First Printed Edition (1633), ed. Andrew Hadfield and Willy Maley, Oxford, Blackwell Publishers, 1997, p. 93. 
The atrocity at Mullaghmast and the death of Rory O'More provide my example of the importance of symbols and rituals in the cultural conflict in Tudor Ireland. Clodagh Tait writes about the propaganda value of a public demonstration of the inappropriate nature of an enemy's death. For Patricia Palmer, the admonitory display of state violence through the spiking of heads and other disfigured body parts was intended to "represent the amputation of the old order: its defunct extremities set out as mutilated trophies to proclaim the triumph of the new $^{32}$ ". The significance of taking and displaying the severed heads of the enemy was taking on a new meaning in the 1570s, signifying the ultimate defeat or the eternal damnation of the victim. The Irish recognized the power of the intended message and Rory Óg's followers both suffered and inflicted significant losses in trying to save their leader's body from the abattoir of English justice: "The rebel's body, though dead, was so well attended and carried away, as it was the cause of the death of a good many of men on both sides; yet carried away it was ${ }^{33}$." Eventually, Rory's head was brought to Dublin and spiked on the Castle walls, but his body hidden away by followers who were determined that their leader's body would not face the dishonor of being quartered and set up as a trophy by his enemies.

It should come as no surprise that the litany of treachery, severity, atrocity, and humility became part of contemporary lore. Sir Brian MacPhelim's murder was a "sufficient cause of hatred and disgust" between the settlers and natives, and the Irish were quick to imitate the violence and the cultural expression of hatred through symbolic acts and the destruction of things. Similarly, the English detestation of barbarous customs was fully reciprocated by the Irish, who communicated their resistance and hostility to the civilized world order being devised for them through the same violence, symbolism and metaphors. Their loathing for English ways was clearly understood by the settler community, who would use it as a rationale for brutal repression in Ireland. Canny claims that ritual mutilations of the English were direct imitation of English practices, and that "the Irish, again in imitation of the English, expressed their defiance of English rule by resorting to symbolic actions $s^{34}$. With brutality and symbolic destruction as primary texts of discourse, the fears and abhorrence of each side for the other was made plain through violence.

32. Palmer, "Writing the Beheading", op. cit., p. 32, 39; Tait, Death and Burial, op. cit., p. 6; Palmer, "Insolent Liberty", p. 315.

33. Brady (ed.), A Viceroy's Vindication, op. cit., p. 101; Lord Walter Fitzgerald, "Historical Notes on the O'Mores and their Territory of Leix to the End of the Sixteenth Century", Kildare Archaeological Society Journal 6, 1909-11, p. 39.

34. Canny, "Dominant Minorities”, op. cit., p. 62-63. 